\title{
The effect of the gene for polledness on conception rate and litter size in the Damascus goat
}

\author{
A. CONSTANTINOU (*), A. LOUCA (*) and A.P. MAVROGENIS (**) \\ (*) Ministry of Agriculture and Natural Resources \\ Department of Agriculture, Nicosia, Cyprus \\ (**) Agricultural Research Institute, Nicosia, Cyprus
}

\begin{abstract}
Summary
Data on 1709 matings and 1247 parturitions were used to situdy the effect of the gene for polledness on conception rate and litter size in the Damascus breed of goat in Cyprus.

With one exception all polled sires used in the study proved to be heterozygous $P p$ for the polled factor $P$.

There was consistent excess of males in the offspring of all mating types with an overall proportion of males $(53.1 \mathrm{p}, 100)$ significantly different from the 50:50 ratio. Intersexes (6.0 p. 100) were found only when both parents were polled ( $P p \times P p$ matings).

The percentage of intersexes corresponds to an expressivity $\gamma_{2}=.48$ of the $P$ genes for that trait in the $P P$ females. Among alpine breeds $\gamma_{2}$ was between .44 and .57 .

The percentage of males in excess corresponds to an expressivity of $\gamma_{1}=.16$ of the $\boldsymbol{P}$ gene for that trait in the $P \boldsymbol{P}$ females ( $\gamma_{1}=.43$ to .56 in alpine breeds). Theoretically this excess must not been found in horned $\times$ polled and horned $\times$ horned crossings where no $P P$ genotypes are produced. This discrepancy, as well as the low value of $\gamma_{1}$ in the $P p$ polled $\times P p$ polled matings has not been explained.

Conception rate for polled $(P p)$ females was 74.7 p. 100 , non significantly different from that of $p p$ ones $(76.4$ p. 100). Litter size at birth for resp. all born and born live kids was 1.88 and 1.82 in polled goats $(P p)$ while it was resp. 1.75 and 1.71 in horned ones. This gives coefficients of surprolificacy of 1.074 and 1.066 in the $P p$ females compared to the $p p$ ones for a value of 1.06 reported in alpine breeds.

There is a light but significant fertility disadvantage of the $P p$ (polled) males compared to the $p p$ (horned) ones which gives a $r$. coefficient of compared fertility of .91 instead of 1.007 observed in alpine stocks. Such a disadvantage is also found at the conception stage.

These slight discreapancies indicate one needs more precise analysis of the behaviour of $P$ gene in the goat.
\end{abstract}

\section{Introduction}

The inheritance of polledness (absence of horns) and its relationship to intersexuality and other forms of genital malformation have been extensively studied in goats, especially in strains of alpine origin (see BOYAJEAN, 1969 for a review). 
It has been well established that practically all polled sterile males from polled parents are homozygous $P \boldsymbol{P}$ for the polled gene, the spermiostasis due to bilateral epididymal stenosis being the main cause of total sterility. Sterile males with hypoplastic testicles on the other hand were identified as masculinized genetic females, homozygous $P P$ for the polled gene (Ricondeau et al., 1972). Polled heterozygous $P p$ females were found to be more prolific than horned homozygous $p p$ females (Soller \& Kempenich, 1964) and fertile homozygous $P P$ polled males as well as heterozygous $P p$ more prolific than homozygous horned $p p$ males RICORDEAU \& LAUVERGNE, 1967 ; RICORDEAU, 1969).

A list of thirteen parameters has been proposed by LAUVERGNE (1969) in order to give a full account of various effects of the polled $P$ gene in male and female goats.

In a study on the inheritance of polledness and its relationship to intersexuality in Damascus goat of Cyprus HaNCOCK \& Louca (1975) found a similar genetical behaviour regarding the polled factor, and concluded that the $P$ gene, as in alpine breeds, was present in this breed.

The purpose of the present work was to further investigate the effect of the gene for polledness on sex ratio, conception rate and litter size in the Damascus breed of goat in Cyprus.

\section{Materials and methods}

The study utilized data on 1709 matings and 1287 parturitions recorded at the Goat Breeding Station of the Cyprus Department of Agriculture over a six-year period (1972 to 1977), including the years (1972 and 1973) which were previously utilized in the study of HaNCOCK \& Louca (1975).

All available information (returns to service, abortions and kidding dates) was used to classify matings as successful (terminated by pregnancy) or nonsuccessful (failure to conceive). Litter size and sex of kids were determined at birth. In view of the occasional difficulty in determining intersexes at an early age it may be possible that some intersexes, which died soon after birth, had been erroneously classified as normal males or females.

The data were pooled across years and chi-square was used to test differences among the various classes. The data on conception rate (conceived $=0$, not conceived $=1$ ) and litter size were, in addition, analyzed by least squares procedures using the following statistical model :

$$
Y_{i j k}=\mu+m_{i}+f_{j}+(m f)_{i j}+e_{i j k}
$$

where :

$\mu=$ an overall mean;

$\mathrm{m}_{\mathrm{i}}=$ effect of the $\mathrm{i}^{\text {th }}$ phenotype (horned of polled) in the male;

$f_{j}=$ effect of the $j^{\text {th }}$ phenotype (horned or polled) in the female ; 
GOAT : POLLEDNESS, CONCEPTION RATE, LITTER SIZE

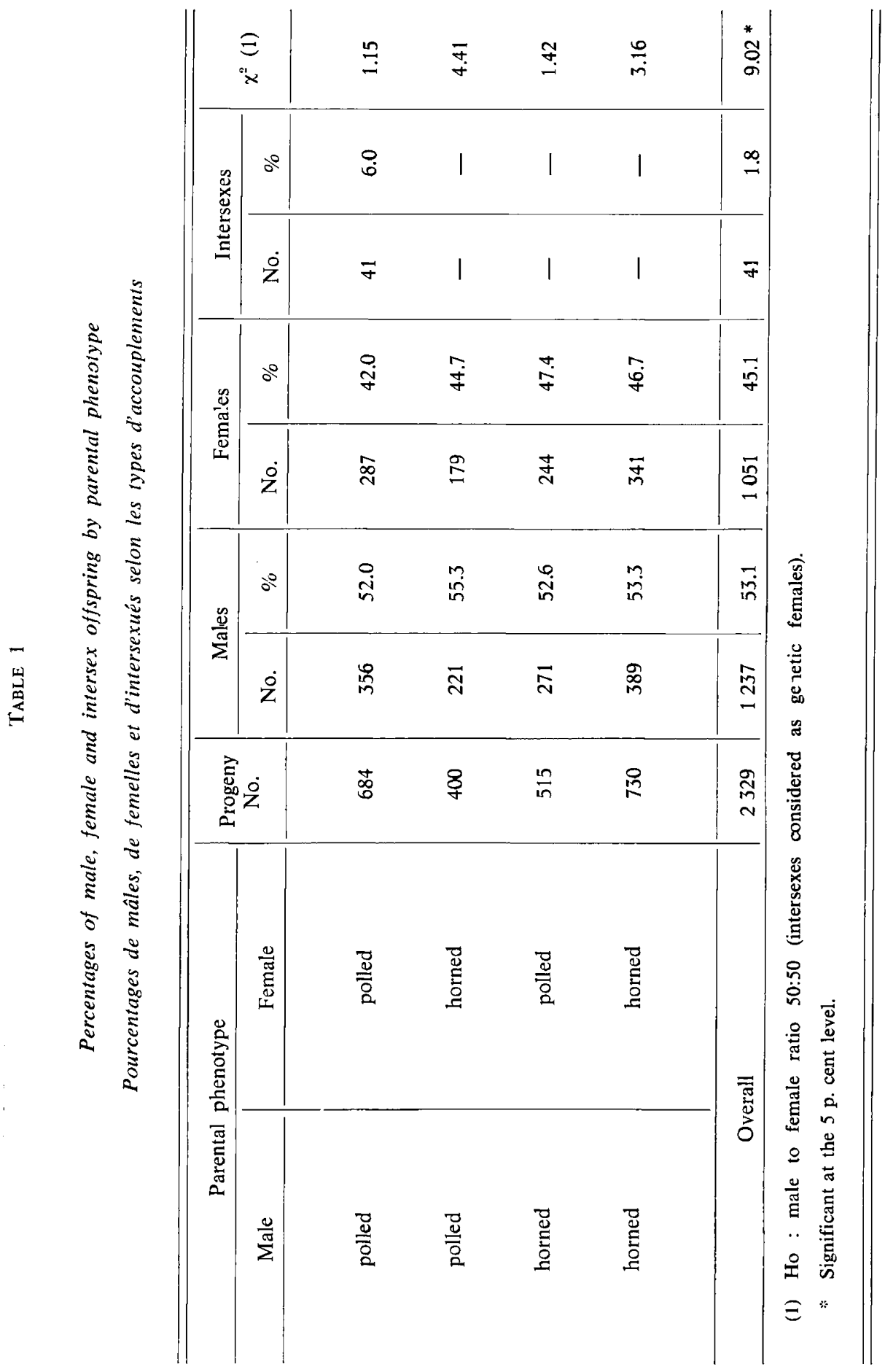


$(\mathrm{mf})_{\mathrm{ij}}=$ interaction effect of the $\mathrm{i}^{\text {th }}$ phenotype (horned or polled) in the male with the $j^{\text {th }}$ phenotype (horned or polled) in the female;

$\mathrm{e}_{\mathrm{jik}}=$ random element assumed normally and independently distributed with zero mean and variance $\sigma^{2}$.

\section{Results}

All males used in the present study had a least some offspring, which shows that none of them was totally infertile. A simple microscopic test of sperm obtained by electroejaculation at the beginning of the mating season may have substantially contributed to this end, since males having ejaculates with no sperm, or with no live sperm, were discarded.

All polled males but one had horned offspring, which shows that they were heterozygous for the $P$ gene. The only male with no horned progeny served only 5 goats of which two conceived, giving birth to 4 polled kids.

The percentage of horned kids in the offspring of polled $\times$ polled and horned $\times$ horned matings was 27.4 and 100.0 , respectively. The corresponding value for matings having one parent horned was $49.5 \mathrm{p}$. 100. The percentage of male, female and intersex offspring in the progeny of the various mating groups is given in table 1 . Intersexes $(6.0$ p. 100) were found only when both parents were polled. There was a consistent excess of males in the sex ratios, the overall proportion (53.1 p. 100) being significantly different from the $50: 50$ ratio of the null hypothesis.

Table 2 refers to the conception rate by parental phenotype. Conception rate was significantly higher $(p<0.01)$ in goats mated to horned males than in those mated to polled males.

TABLE 2

Conception rate by parental phenotype

Taux de conception selon le type d'accouplement

\begin{tabular}{|c|c|c|c|c|c|c|c|}
\hline \multicolumn{2}{|c|}{ Parental phenotype } & \multirow{2}{*}{$\begin{array}{c}\text { Matings } \\
\text { No. }\end{array}$} & \multicolumn{2}{|c|}{ Conceptions } & \multicolumn{2}{|c|}{ Failures } & \multirow{2}{*}{$\chi^{2}(1)$} \\
\hline Male & Female & & No. & $\%$ & No. & $\%$ & \\
\hline polled & polled & 578 & 374 & 72.2 & 144 & 27.8 & \\
\hline polled & horned & 325 & 233 & 71.7 & 92 & 28.3 & \\
\hline horned & polled & 346 & 271 & 78.3 & 75 & 21.7 & \\
\hline horned & horned & 520 & 413 & 79.4 & 107 & 20.6 & \\
\hline polled & & 843 & 607 & 72.0 & 236 & 28.0 & \\
\hline horned & & 866 & 684 & 79.0 & 182 & 21.0 & $11.25 * *$ \\
\hline & polled & 864 & 645 & 74.7 & 219 & 25.3 & \\
\hline & horned & 845 & 646 & 76.4 & 199 & 23.6 & 0.75 \\
\hline \multicolumn{2}{|c|}{ Overall } & 1709 & 1291 & 75.5 & 418 & 24.5 & \\
\hline
\end{tabular}

(1) Ho : Complete independence of the two classifications.

** Significant at the 1 p. cent level. 
The variation of litter size according to parental phenotypes is given in table 3 . Polled goats gave significantly larger litters than horned goats. Goats mated to horned males produced more live kids at birth, but differences in actual litter size, i.e. stillbirths included, were insignificant. Horned $\times$ polled matings yielded 1.92 and polled $\times$ polled matings 1.73 kids per kidding.

\section{TABLE 3}

Means and standard errors of litter size at birth according to parental phenotypes Moyennes et écart-types de la taille de la portée à la naissance selon les types d'accouplement

\begin{tabular}{|c|c|c|c|c|c|c|c|}
\hline \multirow{2}{*}{\multicolumn{2}{|c|}{ Parental phenotype }} & \multicolumn{6}{|c|}{ Litter size at birth } \\
\hline & & \multicolumn{3}{|c|}{ all born kids } & \multicolumn{3}{|c|}{ live born kids } \\
\hline Male & Female & $\begin{array}{c}\text { Observ. } \\
\text { No. }\end{array}$ & Mean & S.E. & $\begin{array}{c}\text { Observ. } \\
\text { No. }\end{array}$ & Mean & S.E. \\
\hline polled & polled & 372 & 1.84 & 0.034 & 364 & 1.77 & 0.033 \\
\hline polled & horned & 233 & 1.73 & 0.043 & 224 & 1.69 & 0.042 \\
\hline horned & polled & 271 & 1.92 & 0.039 & 264 & 1.86 & 0.038 \\
\hline horned & horned & 411 & 1.78 & 0.032 & 399 & 1.73 & 0.031 \\
\hline polled & & 605 & 1.78 & 0.026 & 588 & 1.73 & 0.026 \\
\hline horned & & 682 & 1.85 & 0.025 & 663 & 1.80 & 0.024 \\
\hline & polled & 643 & 1.88 & 0.025 & 628 & 1.82 & 0.025 \\
\hline & horned & 644 & 1.75 & 0.025 & 623 & 1.71 & 0.025 \\
\hline \multicolumn{2}{|c|}{ Overall } & 1287 & 1.82 & 0.018 & 1251 & 1.76 & 0.018 \\
\hline
\end{tabular}

The significance of the effect of the horn phenotype on conception rate and litter size is tested in table 4 . The conception rate of horned females was similar to that of polled females. In addition, no interaction effects among parental phenotypes were found.

\section{TABLE 4}

Mean squares and tests of significance for the effect of parental phenotype on conception rate and litter size

Test de signification de l'influence du type d'accouplement sur le taux de conception et la taille de la portée

\begin{tabular}{|c|c|c|c|c|c|c|}
\hline \multirow{3}{*}{ Source of variation } & \multirow{2}{*}{\multicolumn{2}{|c|}{$\begin{array}{l}\text { Conception } \\
\text { rate }\end{array}$}} & \multicolumn{4}{|c|}{ Litter size at birth } \\
\hline & & & \multicolumn{2}{|c|}{ All born } & \multicolumn{2}{|c|}{ Live born } \\
\hline & d.f. & M.S. & d.f. & M.S. & d.f. & M.S. \\
\hline Polled or horned male (A) & 1 & $1.9467^{* *}$ & 1 & 1.2889 & 1 & $1.5627^{*}$ \\
\hline Polled or horned female (B) & 1 & 0.0039 & 1 & $4.8427^{* *}$ & 1 & $3.3302 * *$ \\
\hline Interaction $(\mathrm{A} \times \mathrm{B})$ & 1 & 0.0263 & 1 & 0.0248 & 1 & 0.1504 \\
\hline Error $\ldots \ldots \ldots \ldots$ & 1705 & 0.1840 & 1283 & 0.4220 & 1247 & 0.3907 \\
\hline
\end{tabular}

* $\mathrm{p}<0.05$ ** $\mathrm{p}<0.01$ 


\section{Discussion}

The results of the present study show that all polled males were probably heterozygous for the $P$ gene. Since the fertile polled females can be assumed heterozygous $(P p)$, the frequency of the gene in the various matings is well established.

If we name $\gamma_{1}$ and $\gamma_{2}$ the expressivity of resp. the pseudomales and the intersexes among $\boldsymbol{P P}$ females (LAUVERGNE's terminology) a frequency of $.5 \times .25 \gamma_{1}$ of excess males to the .5 sex ratio and of $.5 \times .25 \gamma_{2}$ of intersexes is expected in polled $\times$ polled $(P p \times P p)$ matings.

The estimation of $\gamma_{1}(.16)$ is far lower from the range of values in alpine breeds : .43 to .56, according LaUvergne (1969) after Soller \& ANGel (1964) and RicordeAu \& LAUVERGNE (1967). Moreover a similar discrepancy in the sex ratio was also observed in the other mating types where no excess of males was expected. In line with the results of HANCOCK \& LouCA (1975) the excess of males was consistent in all mating types.

Contrary to $\gamma_{1}$ the value of $\gamma_{2}$, already reported by Hancock \& Louca (1975) fits well the previous observations.

The difference in litter size between horned and polled does is in agreement with the findings of Soller \& KeMPenich (1964) and Ricordeau (1969), who reported larger litter size in polled $(P p)$ than in horned goats $(p p)$, and concluded that the $P$ gene in the heterozygous condition may have heterotic effects on female fertility. The superiority of the $P p$ female in terms of prolificacy can be measured in terms of the $t$ parameter of LAUvergne (1969). The values of $t$ for, total kids born and kids born live only, were 1.074 and 1.064 (tables 3, 4), respectively, and are in good agreement with the value of 1.066 reported by LAUVERGNE (1969) for alpine breeds. The value at the conception level not being significantly different (table 2).

Such an advantage, however, was not found for fertility of heterozygous polled males. The coefficient of fertility $\left(\mathrm{r}_{2}\right)$ for $P p$ genotypes compared to $p p$ genotypes was 0.96 for all kids born and 0.96 for kids born live (table 3). These values are somewhat lower than the value of 1.007 given by RiCORDEAU (1969). Since conception failures where the polled males are also handicaped (see table 2) were determined using information on returns to service, abortions and kidding dates only, early embryonic death could be considered as contributing to the differences found between the two groups.

\section{Conclusions}

The behaviour of the $P$ gene in the female Damascus goat fits grossly the theory of the behaviour of the $\boldsymbol{P}$ gene established earlier. Nevertheless, the consistent excess of males in all matings cannot be explained on the basis of the current theory. Moreover, an advantage in fertility of horned over polled males was found in this study. 
These discrepancies indicate the need for a more accurate description of the complex behaviour of the $\mathrm{P}$ gene in the goat.

Received for publication in march 1981.

\title{
Acknowledgments
}

The manuscript has been reviewed by Drs Lauvergne and Ricordeau from the Department of Animal Genetics, I.N.R.A., France.

\author{
Résumé \\ L'influence du gène motte sur le taux de conception \\ et la taille de la portée de la chèvre Damasquine
}

L'influence du gène motte sur le taux de conception et la taille de la portée a été étudié à Chypre en race caprine Damasquine à partir de données de 1709 accouplements et de 1247 parturitions.

A une exception près, on a pu montrer que tous les mâles mottes considérés dans l'étude étaient hétérozygotes $P p$ pour le facteur d'absence de cornes $P$.

Il y avait un excès significatif de mâles dans la descendance de tous les types de croisement $(53,1$ p. 100) mais on a trouvé des intersexués seulement dans les descendances de parents mottes tous les deux $(P p \times P p)$.

Le pourcentage d'intersexués correspond à une expressivité $\gamma_{2}=0,48$ du gène $P$ pour cette manifestation parmi les femelles $P p$. Dans les races alpines, la valeur de $\gamma_{2}$ était comprise entre 0,44 et 0,57 .

Le pourcentage de mâles en excès correspond à une expressivité $\gamma_{1}=0,16$ du gène $P$ pour cette manifestation chez les femelies $P P$. Dans les races alpines, $\gamma_{1}$ est compris entre 0,43 et 0,56 . Théoriquement, ces mâles en excès ne devraient pas se retrouver dans les croisements cornu $\times$ motte ou cornu $\times$ cornu, qui ne produisent aucun génotype $P P$. Cette anomalie, de même que la faible valeur de $\gamma_{1}$ n'a pas reçu d'explication.

Le taux de conception des femelles $P p$ était de 74,7 p. 100, pas significativement différent de celui des $P P(76,6 \mathrm{p} .100)$. Les tailles des portées à la naissance pour respectivement tous les chevreaux et les chevreaux nés vivants, étaient de 1,88 et 1,82 pour les chèvres mottes $P p$, alors qu'il était de 1,75 et 1,71 pour les chèvres cornues. Cela donne un coefficient de surprolificacité de resp. 1,074 et 1,006 pour les femelles $P p$ comparées aux $p p$. Ce chiffre est à rapprocher du chiffre de 1,06 observé en races alpines.

Il existe un léger mais néanmoins significatif désavantage des mâles mottes $P p$ comparés aux mâles cornus $p p$ quant à la fertilité, le coefficient de fertilité comparé étant $\mathrm{r}_{2}=0,91$ alors qu'en race alpine l'avantage est dans le sens contraire $r_{2}=1,007$. Cet écart se manifeste déjà lors de la conception.

Ces légers écarts entre les comportements du gène en races alpines et en race Damasquine indiquent que des études plus précises sont nécessaires. 


\section{References}

Boyajean D., 1969. Bibliographie signalétique : Intersexualité associée à l'absence de cornes chez la chèvre d'origine alpine. Ann. Génét. Sél. anim., 1, 447-463.

Hancock J., Louca A., 1975. Polledness and intersexuality in the Damascus breed of goat. Anim. Prod., 21, 227-231.

LAuvergne J.J., 1969. Progrès des connaissances génétiques sur l'intersexualité associée à l'absence de cornes chez la chèvre d'origine alpine. Ann. Génét. Sél. anim., 1, 403-412.

Ricordeau G., 1969. Sur la prolificité des génotypes sans cornes dans les races caprines Alpine Saanen, Alpine Chamoisée et Poitevine. Ann. Génét. Sél. anim., 1, 537-542.

Ricordeau G., Bouillon J., Hulot F., 1972. Pénétrance de l'effet de stérilité totale lié au gène sans cornes $P$ chez les boucs. Ann. Génét. Sél. anim., 4, 537-542.

Ricordeau G., Lauvergne J.J., 1967. Hypothèse génétique pour expliquer la présence d'intersexués, de mâles en excès et de mâles stériles en race caprine Saanen. Ann. Zootech., 16, 323-334.

Solrer M., Angel H., 1964. Polledness and abnormal sex ratio in Saanen goats. J. Hered., 55, $139-142$.

Soller M., Kempenich O., 1964. Polledness and litter size in Saanen goats. J. Hered., 55, 301-304. 